\title{
Labor Analogous to Slavery: The Construction of a Problem ${ }^{1}$
}

\author{
Angela de Castro Gomes \\ Department of History \\ Fluminense Federal University
}

Angela de Castro Gomes, "Trabalho análogo a de escravo:

construindo um problema”, História Oral 11 (Jan-Dec 2008): 11-41.

Translated by Arthur Brakel

\section{1-Introduction:}

At the beginning of his text titled "História dos conceitos e história social," Reinhart Koselleck writes that it is not facts that unnerve men, but rather what is written about those facts. This observation makes us ponder the strength of words, without which human goings-on and suffering cannot be experienced or transmitted across time. ${ }^{2}$ And this directs us toward the complex and intimate relationship between words and things, between language and social reality, and to the fact that if words are not the things they denote, without words there are no things. Likewise, though words about the world are not all concepts, neither are there concepts without words. As Koselleck demonstrates, concepts are words that occasion a multiplicity of meanings, and by doing so they can make us see (and feel) social reality's complex dimensions. Concepts are always polysemic. They change over time and from place to place, yet they retain a tension in the relationships they establish with the facts they convey.

Words, concepts, and social reality are historians' raw materials. This is perhaps especially the case in my current study of present-day forms of labor, which entails recognition of the institution of compulsory labor in contemporary societies. In Brazil these are bluntly known as "labor analogous to slavery"

1. Translated from the Portuguese by Arthur Brakel. Slightly abridged by the series editors at LACS.

2. Reinhart Koselleck, Futuro passado: contribuição à semântica dos tempos históricos (Rio: Contrapunto/PUC-Rio, 2006), 97. 
or contemporary slave labor. This phenomenon has come to light both inside and beyond Brazil, and has become one in a gamut of issues that politicians, social scientists, and historians of law have had to address. Over the last four decades, the expression "labor analogous to slavery" ${ }^{3}$ has generated increasingly urgent discourse, based on its capacity to mobilize agents who demand public policies to combat the practices it names. It is now imperative that we recognize it as a key new topic in the social history of labor.

Thus the point of departure for this article is the realization that, even though forms of compulsory labor have been with us over time and around the globe, they have not always exhibited the same characteristics. Nor have they necessarily been recognized and interpreted in a consistent way by contemporary social actors. The historicity of these types of labor combines continuity and discontinuity, and alerts us to a tradition of compulsory labor in Brazil and elsewhere. It also allows us to consider the specific features of these traditions in different historical periods. My purpose here is to understand compulsory labor as a new factor in recent Brazilian history. On the one hand, this phenomenon is related to centuries-old practices of worker exploitation; on the other, it possesses unique characteristics that pertain to its emergence and spread in the last four decades.

The development of a specific designation for this phenomenon constitutes, in and of itself, a fact that is replete with both practical and symbolic meanings. These meanings, in turn, help shape the phenomenon's definition and structure. As historians know well, the choice of a particular word or phrase is an act that preserves a relationship with "what already exists" as well as with what they are trying to classify. At the same time, a particular designation can help us analyze the existing reality that we want to learn about. Such tools help us redefine our topic's connections with a nation's history and memory. Those connections clearly reach into the study of memory, and from there to the political uses of the past.

The study of memory is perforce interdisciplinary, and practitioners have recently emphasized the political and collective dimensions of remembering. Myriad social groups increasingly demand the right to construct "their past" and, while maintaining their own specificity, integrate it in the past of broader social groups. This is especially the case with minorities and other groups excluded from the mainstream. Once one realizes that a group's memory is a fundamental factor in establishing its internal cohesion and identity, the construction of pasts and links among pasts entails an intense dialogue between

3. The official term the author uses is "trabalho análogo ade escravo," which literally means "work analogous to a slave's." While this is the term used in the Brazilian code of labor laws, its literal translation is too cumbersome to use in an English-language text, and we have opted for "labor analogous to slavery," which is the phrase currently used by the International Labor Organization in its agreements with Brazil. (Translator). 
memory and history. In the cases of nation states, their institutions, and public and private organizations, the search for a past provides a foundation for their actions and projects and is central to guaranteeing their legitimacy and their temporal continuity.

The political uses of the past, which some authorities refer to as the historical memory of a group (regardless of its size), are proof of the fluid frontiers between history and memory, as well as the cultural appropriation to which events and historical personages have always been subjected as time passes. According to Marie-Claire Lavabre, who has studied the dense relationship between memory and history, "We can refer to past and historic practices as historical memory. Certain social groups, parties, churches, nations and states in turn appropriate these practices. These appropriations can be dominant or can be dominated, they can be both multiple and selective. However they are used, they are marked with the stamp of anachronism when they make the present seem like the past. True history, however, critically analyzes historical memory, and establishes differences between the past and the present."

Dealing with the matter of labor analogous to slavery in recent Brazilian history involves understanding the terminology that shapes the concept and gives it a foundation in the dynamic of political uses of the past. Only in this way can present and past be separated and differentiated, as history takes on the task of understanding the work of memory. Beyond this basic interpretive orientation, it is worth pointing out that construction of the term "labor analogous to slavery" casts light on the most dramatic facets of social processes, which include the precarious nature of workers' rights and the dynamics of internal migration to the cities and to the country's agricultural frontier. Even though the practice and the name we give it are analytically different, they are irrevocably connected. The constitution of a category of "compulsory labor" in present-day Brazilian society and the use of a specific term to designate it reveal key problems in the world of contemporary labor. Even though practices of compulsory labor affect very specific sectors of the labor market, they nonetheless provides a window onto much larger issues related to the regulation of the labor market in Brazil and elsewhere.

This historical problem resembles the old, but not totally hackneyed, tipof-the-iceberg metaphor. That is, we can make out the tip of an immense iceberg of praxis via the nomenclature adopted to identify this new phenomenon. This nomenclature singles out certain types of compulsory labor typical of today's world. Vocabulary is thus a fruitful indicator of social processes, naming

4. Marie-Claire Lavabre. "De la notion de mémoire à la production de mémoires collectives," in Cultures politiques, ed. Daniel Cefaï (Paris: PUF, 2001), 242. Sarah Gensbuerger and Marie-Claire Lavabre, "Entre devoir de mémoire et abus de mémoire: la sociologie de la mémoire comme tierce position," in L'histoire entre mémoire et épistémologie: autour de Paul Ricoeur, ed. Bertrand Müller (Géneve: Payot Lausane, 2005). 
and identifying a form of worker exploitation specific to a particular time and place. My goal is not to challenge the use of this nomenclature, which is more and more widely shared throughout Brazil. But I do try to understand why this particular term, rather than any other, has been chosen to give form to an established fact in the world of work. The adoption of a particular term for a specific phenomenon is a political and cultural event that must itself be taken into account. The choice of terminology becomes a "social fact" in a given experiential context, and the term chosen expresses a process of struggle and negotiation among different agents, who have different political weight. My main focus, then, will be the process that has given rise to general agreement on and adoption of the term "labor analogous to slavery."

\section{The Law and the Historians-or Naming Facts}

On 11 December 2003, the promulgation of Law no. 10.803 altered the wording of Article 149 of the Brazilian Penal Code by revising a 1940 decree. That law originally provided punishment for the crime of imposing forced labor on another:

Article 149: Reducing anyone to a condition analogous to that of a slave: Sentence: A prison term of 2 (two) to 8 (eight) years.

In late 2003 state institutions such as the Ministry of Justice, in cooperation with the Bureau of Human Rights, and in partnership with the Federal Public Ministry, the Public Ministry of Labor, the Ministry of Employment and Labor, the Association of Federal Judges, met with representatives of the International Labor Organization (ILO) in a special session (câmara técnica) on "Present-day Forms of Slavery." This meeting resulted in Article 149 being revised as follows:

To reduce someone to a condition analogous to that of a slave, either by subjecting him or her to forced labor or to debilitating work days, or by subjecting him or her to degrading working conditions, or by restricting, by whatever means, the person's mobility as a result of any debt with an employers or employer's agent.

Sentence: 2 (two) to 8 (eight) years in prison and a fine, and punishment commensurate with any violence that may be involved.

This expansion of what had been understood to be labor analogous to slavery satisfied some but frustrated others owing to the "confusion" that such an expansion could cause, and because of the unchanged length of the prescribed 
prison terms. This recent version of the law thus marked an end point and a new starting point for considerable debate. These debates have involved different players in political and intellectual fields, all of whom are equally invested in combating the contemporary exploitation of human labor. In addition, each faction has struggled to assert its own terminology for the recent forms of labor exploitation. They do this because they all understand that controlling the language around this exploitation can advance their particular public policy aims. They are not merely interested in stamping out these practices, they also advocate the adoption of punitive policies that can help in preventing them; finally, they are committed to developing social policies that generally support workers.

A turning point came under the "New Republic," after the end of the military government that had been established in 1964. The José Sarney administration created in 1985 the Ministry of Development and Agrarian Reform (MIRAD), whose actions mark the moment when official documentation acknowledged the existence in Brazil of exploitation commonly designated as "slave labor." If that ministry's action was short-lived, its use of the then common term has lived on. The term "slave labor" had been used in institutional discourse within civil society, including, since the 1970s, that of the Catholic Church. The term has become more and more prevalent in governmental texts. Thus, when we discuss the matter of labor analogous to slavery in early twentyfirst-century Brazil, we are no longer seeking simple recognition or condemnation of the institution. Instead, the aim is to come to an agreement about the best way of legally, politically, and academically constructing a problem that characterizes contemporary labor, one that can promote both national and international mobilization. The "name" becomes a powerful tool when demanding action from the state-most especially the state's ability to change a law. Through its deployment by the press and non-governmental organizations, a name can also influence public opinion.

I shall first try to provide a brief history of the terms used in this stillongoing discussion in Brazil. From a legal perspective and that of the social sciences and especially Brazilian history, we can say that making clear what "labor

5. There is a whole series of works that we consider fundamental to the study of this matter. They will be taken up later in this article. They are: Neide Sterci, Escravos da desigualidade: um estudo sobre o uso repressivo da força de trabalho hoje (Rio: CEDI, 1994); José de Souza Martins, A sociabilidade do homem simples (São Paulo: Hucitec, 2000); Ricardo Rezende Figueira, Pisando fora da própria sombra: a escravidão por dívida no Brasil contemporâneo (Rio: Civ. Brasileira, 2004); Regina Beatriz Guimarães Neto, A lenda do ouro verde: política de colonização no Brasil contemporâneo (Cuiabá, Mato Grosso: Unicen. 2002). João Carlos Barrozo, ed., Mato Grosso: do sonho à utopia da terra, Cuiabá (Matto Grosso: UFMT, 2008); Gelba C. Cerqueira and others, eds., Trabalho escravo contemporâneo no Brasil: contribuições críticas para sua análise e denúncia (Rio: UFRJ, 2008); Isabel C.M. Guillén, "O trabalho de Sísafo: escravidão por dívida na indústria extrativa da erva mate (Mato Grosso 1890-1945), Vária História, 23, 38 (July-December) 2007: $615-36$. 
analogous to slavery" is has always been fundamental to the parties involved. We needed to differentiate it from other irregularities, and even from the grave flouting of national and international norms of workers' rights. The law of December 2003 has been, for some, a solution to the problem of what parameters should be adopted to define the phenomenon. The law aims to clarify the term for its agents-be they in the Ministry of Employment and Labor, the Public Ministry of Labor, or the federal courts or labor courts.

Some observers consider that the 2003 law represents only a complication. Because of its length, rather than isolating and clarifying "labor analogous to slavery," it conflates the term with other forms of egregious exploitation. On this view, it does nothing to illuminate the actual nature of this new social phenomenon. However, what is important in this debate over the letter of the law is the general recognition that greater explicitness in defining the problem is crucial. A better definition would identify more effective actions for combating such practices; it would more appropriately punish exploiters; and it could provide support and protection for the exploited. This is not merely a question of semantics, it is a matter of establishing a solid understanding of a category from which social reality can be powerfully interpreted, and public policy unleashed, not only to prosecute those guilty of exploitation, but also to guarantee the rights of those being exploited. Clearly, in the absence of a common terminology, there can be no unified political action.

An account of this debate, carried over into the field of history, must refer to the excellent piece by Eduardo França Paiva, "Trabalho compulsório e escravidão: usos e definições nas diferentes épocas [Compulsory labor and slavery: Usage and definitions in different periods]." ${ }^{\prime \prime}$ In this text França Paiva describes the state of the art in historians' arguments and concerns vis à vis this matter-especially those of scholars who specialize in the history of slavery. To begin, he documents the existence over time of different forms of compulsory labor. He sees compulsory labor as a term that refers to different types of exploitation at different times-servitude, corvée labor, Church exactions, and encomienda, as well as slavery. All these institutions had "legitimate" and legal ways to force laborers to work. They were each part of a larger social context in which labor relations were fundamental, but embedded within other contexts. In the case of chattel slavery, França Paiva points out that there never was "slave labor," rather there was work done by slaves, who were, according to Roman law, people born as or made to be someone's private property. This implied that enslaved women's offspring would be slaves. These notions made up the judicial basis for what historians have generally termed "modern slavery," i.e.,

6. I wish to personally thank the author, a colleague and a friend. He has let me have his 2005 text, which is still unpublished. Moreover, when I have been in doubt, he has encouraged me to carry these deliberations to their conclusion. 
slavery as it existed between the sixteenth and nineteenth centuries, when European colonialism spread around the world.

With the point made that slave labor is a sub-species of a larger categorycompulsory labor-França Paiva examines the historiography of slavery in Brazil, as a way of situating the categories for possible use in understanding the past and the present. He maintains that between 1950 and 1980 the study of slavery bore a strong Marxist orientation (both structuralist and instrumentalist), which interpreted modern slavery as a practice typical of "peripheral capitalism." Thus it was a form of domination centered in the world of work. Based on longstanding legal definitions in academic texts and educational handbooks, this current of writing considered slaves to be "things." However, in his view, this interpretive current tended not to acknowledge that slaves have also been agents of history. It neglected the slaves' own varied political and cultural actions over time, even as it denounced the exploitation they experienced.

It is not my intention to explicate in any detail the different critiques of this Marxist historiography by post-1980 historians. Briefly, they have identified the inadequacies of the model of dominance relationships, seeing it as asymmetrical, dichotomist, and Manichean. They have also addressed the reification of slave workers that resulted from bracketing them within the contrasting dichotomous notions of "slave-as-object" or "slave-as-rebel." These dichotomies left no room for perceiving individual creativity, or for individual or collective choice among their subjects of study. Indeed, in recent studies we see a sharp weakening of the Marxist matrix in the study of slavery. ${ }^{7}$

Recent scholars have constructed a sophisticated alternative interpretive model, one that affirms both theoretically and empirically that slave laborers were subjects of their own history as well as of Brazilian history. In his 2005 essay, França Paiva expressed apprehension that this effort would be threatened by the return of outdated notions that could accompany the growing use of the expression "labor analogous to slavery." In his thinking, this designation, besides being anachronistic since there is no longer a slave-holding structure in Brazil, might reawaken the notion of a historic player, "the new slave," a person seen as an alienated, dehumanized, and degraded being. His apprehension certainly has some justification, since this was how slaves appeared in the dominant interpretive matrices up to the 1980s. One of his specific fears concerns the risk of anachronism in terminology, an apprehension that I contend needs to be reconsidered.

The point in adopting the term, I would argue, is not to displace the term in time, removing it from its proper historical context, and thus risking in-

7. On this matter see my own evaluation: Angela de Castro Gomes, "Questão social e historiografia no Brasil do pós-1980: notas para um debates," Estudos Históricos, História e Imagem, $34,2004,2$. 
correct interpretations. Instead it can be seen as opening a "path" that can be followed, keeping in mind the relations between memory and history. Trying such a tack could be quite revealing. The term may indeed carry what MarieClaire Lavabre calls "the mark of anachronism," but this not because the term is being used incorrectly by the various social players, including historians. Rather it is because the vocabulary employed makes an explicit appropriation of the past. This redeployment of "slavery" packs new meanings specific to its present context. It becomes a new concept expressed by an old word, in the way that Koselleck had phrased it. ${ }^{8}$

Another objection, and perhaps França Paiva's main one, is that by using old terms we might be putting at risk a hard-won collective effort to make sense of modern slavery, and to see slaves' actions as subjects. This is why he maintains that this label has been employed in a stereotyping manner that sees slaves as mere victims. This concern comes from the expression's having been devised within projects that are primarily political rather than academic. Even though he recognizes the term's social acceptance and political value, França Paiva asserts that its use in historiography is both dangerous and mistaken. This is a weighty warning.

It is worth examining more closely the struggles within which the term has emerged. Primary among these are the activities of the Catholic Church. More than a decade after its activation by the Church, the term was adopted by some state actors within the executive and judicial branches. It eventually acquired currency in the media, where it became familiar and was used freely. Beyond the media, members of the established power structure also used the term. But here is the point: There were alternatives to the current term, and a choice was made. And how that choice was made reveals its political content.

There is one additional issue: when a particular term is used to excess, as some believe is the case with "labor analogous to slavery," it can completely lose its capacity to give meaning to what it is meant to designate, since across its usages it ends up referring to an endless number of quite different phenomena over space and time. While being attentive to these problems, I shall begin to examine the process by which this actual concrete social phenomenon has been identified, and a set of words assigned to name it. ${ }^{9}$

While we as historians acknowledge that this label bears a "stamp of anachronism," we should also keep in mind that it is meant to designate a phenomenon peculiar to the late twentieth and early twenty-first centuries. These tensions did not prevent the term's inclusion in the revised article in the 2003 Penal Code, nor have they inhibited its growing use across Brazilian society.

8. Koselleck (op. cit.) points out that new concepts represented by old words acquire other meanings over time.

9. This text is the first product of a wider research project I am working on with Regina Beatriz Guimarães (UFPE). We plan to complete it in the next few years. 
Consequently we must pay close attention to how this category is appropriated, and stay alert to its new meanings in distinct historical contexts. ${ }^{10}$ These meanings energize links to the past and selectively recreate and use elements of the past according to present-day objectives. Even though the phrase "labor analogous to slavery" had been present in Article 149 of the 1940 Penal Code, it had not attracted much attention within the academy, nor did it initially shape public policy or mobilize non-governmental organizations here or abroad. But category of compulsory labor has gone on to acquire new meanings in more recent historical contexts. These transformations have come about as a result of the globalization of our economy and the increasingly precarious nature of traditional social relationships that had established identity boundaries in families, in school, and at work.

It was in the 1970s in Brazil that the category became active, attained its legal and political standing, and became a powerful resource for social mobilization. The issue at hand, then, is not so much the term's existence tout court, but rather how it acquired its meanings and just what it encompasses in addition to its new political force. That story must track the interventions of a series of social players after the 1970s.

It may be worth noting that this category of labor became current after the publication of a series of powerful and widely acclaimed studies on the subject of "modern slavery" in Brazil. These studies also addressed the world of "free labor," and converged in constructing a new paradigm for interpreting dominance in relationships. As França Paiva points out, within this new approach, slaves were not "objects," nor were they seen as "dehumanized." In this new historiography there were only "active subjects," constructing their own world views and acting creatively, notwithstanding varying degrees of constraint.

As historians put together compelling accounts of a particular problemslave labor in a slave-holding system - the problem then seemed to "reappear" in a very different and highly politicized context. This has led some historians to fear that as the category of compulsory labor was reaffirmed and consecrated in the letter of the law after 2003, viewers might see contemporary workers subjected to forms of compulsory labor as "new slaves," once again considered solely as "objects." Perhaps. But it is worth remembering that the new paradigm actually sees historical actors as subjects rather than victims and this, we believe, is being incorporated into academic work on "labor analogous to slavery," albeit with certain difficulties and imperfections. That is, in practice, contemporary historical dialogue continues to engage the advances made in the literature on slavery in the colonial and imperial periods.

Beyond this, the Constitution of 1988, which recognizes the legitimacy

10. I use the category "appropriation" as Chartier has formulated it in several different texts. See for example Roger Chartier, História cultural: entre prática e representações (Lisboa/Rio: DIFEL/Bertrand, 2008). 
of demands for land by communities descended from slaves, has inserted the politics of memory into our social dynamics and into the academic debates. ${ }^{11}$ The rights of Africans' descendants to reparations have been recognized by the State in its affirmative action policies, and these must be considered to be one more background element in the construction of policies against labor analogous to slavery, even though the relationships between the old and new categories of compulsory labor are neither direct nor simple. Indeed, on the issue of land claims, historians have also lined up with different sectors of the government bureaucracy and within social movements of various sorts-especially with the Afro-Brazilian movements-confronting and, in their view, overcoming the gap between historical research and contemporary assertions of right.

One solution to the problem of complex meaning, of course, would be to keep the term "labor analogous to slavery" out of our historiography. But the interpretation I advance here would instead involve adopting the term as an object of the study linked to present day phenomena concerning the activation of group memory. Why and how was such a term chosen to designate a social fact as complex as this one? Was it, as some argue, "induced" by the International Labor Organization? Why did these words and not others become common in Brazilian society?

As historians we know that social facts are not objects, but they are named and identified by the actions of historical subjects who are invested in the production and propagation of these "facts." We also know that if a particular category achieves social currency and becomes a sure indicator of some "fact" in reality, it is because it has established a network of meanings within a specific social group. It is neither an arbitrary nor a whimsical creation. For all these reasons, it is relevant to investigate the phenomenon known as "labor analogous to slavery" as both a "name" and as a "thing."

\section{3 - The Law and Politics-or The Production of Social Facts}

Debates around the matter of "labor analogous to slavery" have also taken place among the diverse actors in the fields of politics and law who are trying to combat it. These include sectors of civil society such as members of the Catholic Church-affiliated Pastoral Land Commission, militant members of non-governmental organizations like the Instituto Carvão Cidadão in the state

11. The French category devoir de mémoire, memory's obligation, is an attempt to take this on internationally by recognizing the obligation to offer redress for historical injustices suffered by specific social groups, such as the descendants of Holocaust victims. I shall not address that matter because there is already an abundant literature on it, including Luciana Heymann, "O devoir de mémoire na França contemporânea: entre memória, história, legislação e direitos," in Direitos e cidadania: memória, política, e cultura, ed. Angela de Castro Gomes (Rio: Editora FGV, 2007), 15-44. 
of Maranhão, and various business-related groups. Among those connected to the state and the judicial system we would include district attorneys from the MPT (Public Ministry of Labor) and federal and labor magistrates. Within the Executive Branch, inspectors from the MTE (Ministry of Labor and Employment) have spearheaded the fight against this practice, with help from the federal police and the highway patrol.

To trace the actions of two principle players-the inspectors in the MTE and attorneys in the MPT-we are drawing upon a set of interviews about compulsory labor in contemporary Brazil. The interviews come from two different but complementary research projects, and they attempt to get inside the cognitive processes of those who are closely involved in these activities. ${ }^{12}$ Some of the interviewees have also published scientific articles and popular press pieces that exposed and discussed aspects of the problem, with which the authors had extensive first-hand experience. I also rely on two articles cited above, and secondary sources of various sorts. ${ }^{13}$

Ruth Beatriz Vasconcelos Vilela, a labor inspector and Secretary of National Supervision in the Ministry of Labor and Employment (1995-1999 and 2003-2006), sees the key campaigns as having begun in the Ministry, and she credits the Itamar Franco administration as being the prime mover. The initiatives it put in motion then extended into President Fernando Henrique Cardoso's first administration, thus covering roughly the first five years of the 1990s. According to Vilela, accusations of inhumane worker exploitation, especially in the agricultural sector and in an area known as Legal Amazônia, were nothing new. But the abuses occurred with greater frequency and intensity in the latter half of the 1980s, as it became clear that the armed forces would soon relinquish their hold on the government. The denouncer with the greatest legitimacy and political weight was the Catholic Church's Pastoral Land Commission (CPT) under the leadership of Dom Pedro Casaldáglia.

It is clear from Vilela's testimony that the Ministry of Labor and Employment (MTE) had heard about rural worker exploitation, and denunciations of it, for some time. What changed in the 1990s was the larger political context, beginning with the promulgation of the 1988 Constitution. This change also came out of the desire to construct a new image for the Brazilian state

12. The Pronex Project known as "Rights and Citizenship," which I directed between 2004 and 2007, was one. It included a study called "History of Labor Rights and Justice in Brazil," which entailed seventy hours of recorded interviews. The other project, "The History of the Ministry of Labor and Employment," was also carried out under CDPOC/FGV between 2005 and 2007 and entailed forty-five hours of recorded data. I am most grateful to all the interviewees and to my colleagues who did the interviewers.

13. Given the topic's currency, I also refer to several articles available on the websites of the MTP and the National Association of Labor Magistrates (Anamatra), among others. Historical writing on this matter has been very thin. Most coverage comes from sociologists, anthropologists, and lawyers-which highlights historians' late entry into this area of research. 
on the heels of its troubled first presidential election after the military regime. Fernando Collor's election, his subsequent impeachment, and his resignation made news around the world. A second factor was the accusation sent by the Pastoral Land Commission to the International Labor Organization in Geneva, which was about to come under consideration. Providing a clear response to the accusation was paramount. Given these political circumstances, the new head of state, Collor's vice president Itamar Franco, and his government had to find a strategic position against these modern and radical forms of worker exploitation.

During that time, i.e. in 1993, owing to pressure from organized movements in civilian society, especially that of the Pastoral Land Commission, the matter became relevant not only because of accusations sent to the International Labor Organization, but also because of challenges coming from several different social institutions at that time. I am not ashamed to say that even though I started my career as an inspector in 1975, I only became aware of and began to have direct contact with slave labor beginning in 1993, when I became Adjunct Secretary in the National Office of Labor Inspection in the Ministry of labor. [...]

In 1993 the first orienting guidelines came out outlining procedures for us to deal with forced labor and slave labor. That was when I was working with Minister Walter Barelli. Those guidelines were the first official act to make National Labor Supervision one of the agencies responsible for eradicating slave labor. ${ }^{14}$

Thus, beginning during Fernando Henrique Cardoso's first administration, the National Office of Labor Inspection attempted to find a form of action by which it could efficiently manage a problem that had no precedents in the history of the Ministry. Notwithstanding the several accusations made during the 1970s and 1980s, "the Office of Labor Inspection experienced difficulties in coping with the matter because it was the job of the Federal Police to deal with the abuse of workers." 15 The development of procedures to combat "labor analogous to slavery" turned out to be a surprisingly simple operation. Vilela made use of an existing decree, the ordinance for the inspection of working conditions. Its terms were ones that were internationally recognized, already envisioned the possibility of establishing what would come to be called "flying squads," charged with inspections. "No one had ever used that article. On top of that I think that no one had even noticed it. Thus it was somewhat interest-

14. "Trabalho escravo no Brasil: depoimento de Walter Barelli e Ruth Vilela," Estudos Avançados, vol. 14, no. 38. São Paulo, jan/abr, 2000.

15. Ruth Vilela, "Depoimento concedido ao projeto História do Ministério do Trabalho e Emprego," CPDOC/FGV, 2006, tape 2, 25. 
ing, since, truth be told, I didn't have to create a thing. I could use a legal provision that was already on the books." 16

But for this to work out, the central MTE Office of Labor Inspection had to coordinate and direct, because "we didn't have the slightest idea about what we would find, nor did we know how we would act." The four years beginning with 1995 and ending in 1998 entailed many trips through the Brazilian hinterland and many different experiments that amounted to an apprenticeship for members of these mobile groups. Those experiences shaped their modes of action in many different senses. One team that was formed in Brasília, so as to guarantee uniformity, efficiency, and secrecy, had to keep local authorities out of the loop. But the results were generally good, making possible the deployment of inspections within 72 hours if necessary. But if the Special Mobile Inspection Groups worked well, the same cannot be said of the so-called Executive Committee for the Repression of Forced Labor (GETRAF). Its aim was to transform repressive conditions according to a governmental plan, and for this it needed the cooperation of other ministries: Agriculture, Environment, Land Tenure, Justice, and the Ministry of Industry and Commerce. Its outcomes were abysmal, basically because the other ministries chose not to participate.

Several points in Vilela's testimony need to be addressed. First, how could the "discovery" of this problem have been a recent event for inspectors, especially the most experienced among them, or those who had long occupied positions in the national bureaucracy? Second, it is troubling that once the MTE had devised a control mechanism in the form of the Special Mobile Inspection Groups, the "discovered" abuses suddenly became apparent. Third, how could there have been no precedents for such action over the sixty-year existence of the Ministry of Labor? Even if one accepts that the rights of rural workers only began to be recognized in the 1970s, the ministry had certainly been familiar with various types of rural labor exploitation.

Finally, how was it that the problem was both identified and suppressed almost simultaneously? This implies a parallel process: categories were created to give the phenomenon a name just as ways to fight it were also created. Both processes necessarily entailed struggle-for creditable positions and in negotiations that could lead to settlements. Indeed, in the interview Vilela uses the terms "slave labor" and "forced labor," terms that were adopted by the GETRAF itself at the time.

Given all this, it is helpful to see a bit more of how the category's configuration itself defined the labor abuses both politically and legally. That configuration was a result of the efforts of various groups directly involved in attacking labor exploitation, in particular the supervisory auditors and the labor attorneys. According to Vilela's testimony, in the early 1990s auditors were 
clear about the importance of settling on a single term for the phenomenon. But the very same auditors knew and used several different terms in their reports: "forced labor," "degrading labor," and "slave labor." As they saw it, the term and its definition would be decisive for the outcome of the battle they had undertaken-especially as far as legal particulars were concerned. In other words they had to understand what they were talking about, especially when it came to punishment of the guilty parties.

Truth be told, the debate about terminology owed its origin to the fact that the International Labor Organization used the term "coerced labor" (trabalho forçoso) for the phenomenon here in Latin America. For the ILO the concept of forced labor says it all. Here are two of their examples [.. .]: those children and teenagers who, sooner or later, are obliged to participate in guerrilla warfare in some African countries [...]; those Chinese political prisoners who are made to work and produce items without being paid. Forced labor is when some higher authority makes someone work without being paid. However in Brazil the case of slave-like labor is totally different. It is well defined in our penal code even though jurists and researchers are always claiming that the concept is not clear and that there is room for doubt concerning it.

The ones who most vehemently argued for the term "slave labor" rather than "forced labor" were the supervisory inspectors. We began by insisting on there being a difference between forced labor and slave labor, and over and over we published our arguments reaffirming the difference. Even the ILO accepted the term "slave labor" for the Brazilian case. ${ }^{17}$

According to Vilela the debate turned into a sort of campaign, which was led by the supervisory inspectors themselves. Their aim was to promote the term "labor analogous to slavery" as the most precise for the Brazilian case. It identified our problem within what the ILO recognized under the broad heading of "forced labor." According to the ILO, the relationship known as "labor analogous to slavery" was one characterized by a total absence of rights. That is, case in which there were absolutely no recognized workers' rights. There would be no contract, and the "employer" appropriated all profits through coercion. That coercion typically extended into the worker's private life. Workers had no objective means of ending the relationship because they felt threatened and/or physically or morally constrained. These characteristics identified this particular labor relationship and differentiated it from any other relationships that could be considered normal, notwithstanding some acknowledged irregularities. The "modern" type of coercion that deprived workers of their liberty 
through the use of several and subtle means came to be seen as violating not only workers' rights, but also human rights.

An understanding of this category's trajectory and meaning is reinforced by the testimony of Jose Cláudio Monteiro de Brito Filho, an attorney in the Public Ministry of Labor for the $8^{\text {th }}$ Region (the State of Pará).$^{18}$ As he recounted his work between 1993 and 1996 in the Coordinating Committee for the Protection of General Interests in Belém, Brito Filho acknowledges that

[...] in our struggle against illicit labor in the countryside, we did not refer to every case as labor analogous to slavery. [...] This was an extremely early stage in the Public Ministry of Labor's activity in this area. It entailed the transfer of the merely supervisory roles of judges in the courts, with their denunciations and proceedings in general, to a more positive attitude in which we began to undertake our own operations.

During that time, even though people were using the term "slave labor," we did not have a particularly clear definition of what it was, and here in the Public Ministry of Labor we weren't sure whether the magistrates would see this matter our way. [...]

I think that we in the MPT and in the Labor Courts grew up together regarding this matter. What we considered slave-like labor or forced labor, as the ILO would have it, were extremely serious and air-tight cases. But I think that the situation got to a point where everyone had a better idea of the matter. But we still have a long way to go because Article 149 of the penal code, which defines labor analogous to slavery, was emended to include work in degrading situations. Once that happened, led by the ILO, throughout Brazil we began to discuss whether degrading work that did not restrict workers' freedom was in fact labor analogous to slavery.

As Brito Filho makes perfectly clear, this category, already present in the Penal Code of 1940, began to be used in the legal profession just as the very problem it refers to was brought to light. This was at the beginning of the 1990s, when in Brazil the Public Ministry of Labor assumed its new functions. Indeed, within the MPT the term had not generally been used earlier, even when actions pertaining to the central problem (labor seen as analogous to slavery) were undertaken.

The change in terminology signaled a recognition that the phenomena were not simply a matter of workers' rights; these practices affected in addition workers' rights as human beings. Brito Filho also explains that back then

18. All quotations here come from the same interview: José Cláudio Monteiro de Brito Filho. Testimony to the project titled "História dos direitos e da Justiça do Trabalho no Brasil," CPDOC/FGV, 2005, tape 1, 15-16. Dr. José Cláudio was the chief attorney for the MPT in Belém, the capital of Pará. 
there was a debate about the aptness and likely reception of the category of abuse-especially among magistrates, be they of the Labor Courts (likely more accepting), or of federal or state courts. In light of the rewording of Article 149 in 2003, one immediate problem was its failure to identify which legal branches had jurisdiction to address these matters. This was only settled in 2006, when the federal courts were assigned this responsibility. ${ }^{19}$ That development pleased those most directly involved in the suppression of this exploitation. They had understood that lack of clarity about jurisdiction was one of the greatest obstacles to bringing the guilty to justice. They applauded the designation of the federal courts, because they were further removed from local pressures. Federal courts would be more effective in assigning sentences that had proved to be hard to enforce locally, notwithstanding governmental sectors' and civil society's systematic efforts.

The convergence of opinion between Vilela and Brito Filho can be further reinforced by Roger Plant's commentary in a 2005 interview with Revista da Anamartra (the National Association of Labor Magistrates). ${ }^{20}$ Plant headed the International Program against Forced Labor of the ILO. When asked why the ILO adopted the term "forced labor," he explained that it had been used since 1930, when the ILO approved General Agreement no. 29. This was the first international pact on forced labor, and was reaffirmed in a second accord in 1957. Its objective was to abolish the existence of labor of that kind throughout the world. The choice of terminology reflected the pact's response to forms of labor exploitation common in areas under colonial rule, especially the exploitation of colonized populations in regions with scant industrial development. In addition, both in 1930 and in 1957 the ILO considered forced labor to be particular to certain states, e.g. where people were subject to a state's political and economic domination. This was recognizably different from the new forms of forced labor first identified in the last decades of the twentieth century. Now the culprits are generally businesses, however constituted, and private individuals, rather than any public powers. For this reason and in this new context, the ILO has pressured governments to take responsibility for combating the proliferation of forced labor, and for avoiding any weakening of extant legislation regulating the workplace and workers' rights.

This last provision becomes especially important in light of the international rise in neo-liberalism since the 1980s, which has fostered the turning back of worker protection laws that had been widely shared since the 1920 s

19. On 30 November 2006 the Federal Supreme Court (STF) assigned jurisdiction to federal courts to judge crimes involving reducing workers to labor analogous to slavery, and resolved the conflict between federal and state courts. This extraordinary petition entered the Supreme Court's docket in 2003; the case began in March 2005 and it was decided at the end of 2006. http://www.mj.gov.br/sedh/ct/notícias2asp?id=1522 (accessed 10 July 2007).

20. http://www.anamatra.org.br/publ/periodicos/rev (accessed 23 February 2005). 
and 1930s. The new forms of forced labor have been directly stimulated by destabilization and deregulation of the labor market, both of which are to some extent the by-products of technological innovation. In addition, labor unions around the world have been in retreat. The migratory fluxes of the globalized economy have turned immigrants into easy targets of labor exploitation, owing to their universal vulnerability. This phenomenon occurs in both rural and urban settings, and in more and less industrialized countries. Further, abusers have turned to "much more subtle coercive and deceitful mechanisms to exploit human beings."21

Due to this problem's seriousness and scope, the ILO for the first time in its history has organized a pro-active program, one that Roger Plant has coordinated. It offers technical and legal assistance to countries that wish to eradicate these new forms of exploitation. When Plant came to Brazil to address its labor magistrates, he, notably, gave passing marks to the actions undertaken by the executive and judicial branches of the Brazilian government. Plant observed, "Little by little you are identifying the worst cases of abuse entailing physical violence and total lack of freedom. You are searching for a route toward a vigorous campaign to stop this exploitation. [...] Therein lies the importance of the term 'slave labor' in Brazil."

In Plant's estimation, the term linking Brazil's forced labor practices to slavery is a useful tool for picking out a phenomenon that is difficult to isolate. In the term itself we find a strategy for establishing public policies to fight the practice. Forced labor is in fact a phenomenon that is very difficult to assail frontally. According to Plant, its forms are specific to different national contexts, and they cannot be addressed by setting out general or broad criteria. In my reading of Plant's judgment, when the ILO accepted the concept of "labor analogous to slavery" for the Brazilian case, it was in recognition of the term's capacity to rally the agents involved in combating forced labor. The ILO's long-standing category of forced labor has not been abandoned, but now functions as an umbrella concept that permits adjustments according to specific realities. "Labor analogous to slavery" is one of those adjustments, made to fit the Brazilian case.

Given all this, let me offer a few observations. First, Brazil's legal category grew out of denunciations of various coercive practices and efforts to combat them. It does not define some centuries-old practice of worker exploitation, but rather a specific set of practices that have spread with the socioeconomic transformations of the last forty years. Second, the movement against this exploitation involved sectors from civilian society (including the Pastoral Land Commission) as well as governmental agents, and these parties demanded that this category be the standard for Brazil. It was not an external imposition by the ILO. 
Why was this term chosen and not another? There is no evidence that designations such as "forced labor" or "servitude" would have failed to generate political energy - the former was widely used internationally and the latter was known in Brazil, as in the expression "servitude for debt," which was very common in the North and the Northeast. But it is also impossible to ignore the potent imagery the chosen term would have for the Brazilian public, since the nation's history is marked by centuries of slavery. Thus the struggle to adopt the term "labor analogous to slavery" can be understood as a clear example of what the literature dealing with memory and its relationship to history calls "usage from the past." This "usage" constitutes a re-reading and a re-signification of the past through present-day optics. It represents a political strategy by which the relationship between history and memory is mobilized as part of demanding one's rights, in this case human rights linked to labor conditions.

Since the Penal Code had long contained an article stipulating punishment for the crime of "reducing someone to labor conditions analogous to those of slavery," there was also precedent for adoption of the term. Beginning in the 1990s it nonetheless began to be challenged by a few jurists who portrayed the concept of slavery as part of a legal tradition that no longer obtained in contemporary industrial societies. They held that confusion around the terminology would impair the process of punishing the guilty, since they could argue that they had no slaves. ${ }^{22}$ From this perspective, the term would be inadequate to "identify the crime," and contrary to the hopes of its proponents, might contribute nothing to the struggle against forced labor in Brazil.

\section{4 - What to do with the concept "labor analogous to slavery"?}

The controversies around the use of this category, that is, about defining the phenomenon itself and devising means to oppose it, are complex. I do not intend to resolve these here, but merely to try to identify dimensions that are central to the debate. In the first place the debate involves connecting certain points in the history of Brazilian society. As they address labor analogous to slavery in the twentieth and twenty-first centuries, participants who advocate the term both approach and distance themselves from the slave labor of the sixteenth to the nineteenth centuries. The concept's expanded inclusiveness and reconfiguration in Article 149 of the 2003 Penal Code provides another twist to the story. In conclusion, I hope to encourage reflection on the reasons

22. One example of someone taking this position comes from Roberto Santos, an appellate judge of the TRT (Regional Labor Court) in the State of Pará. Roberto Santos, Depoimento ao projeto História dos direitos e da Justiça do Trabalho no Brasil, CPDOC/FGV, 2005. Tape 2, $17-20$. 
that justify both the choice of term and in particular the term's acceptance and dissemination, notwithstanding the difficulties entailed in its use-especially among professional historians.

The supervisory inspectors and attorneys see the term as calling up a powerful collective of associations: slaves, slavery, and the consequences thereof. By its use they have both moved toward and retreated from Brazil's slave-holding past. And they have mobilized a highly charged and very present national memory, owing to recent demands for redress made by Brazilians whose ancestors were slaves. That is, when they refer to and re-engage Brazil's slaveholding past, their aim is to highlight the extent to which such a practice has been judged unacceptable and intolerable ever since its banning under the 1888 Golden Law, which Brazilians consider to be a civilizing and liberating landmark.

Where the auditors and attorneys rely less on the connection to historical slavery, their aim is to show how the practice has completely changed. It is an entirely new phenomenon and not simply a return to what is called in school and in books "slave labor." This is why, throughout their testimony, they expose the novelty of-and express their revulsion at-the new abuses as fact. They are careful to note how much more insidious such abuses are than those of late nineteenth-century slavery, just prior to formal abolition.

The reflections of one supervisory inspector, Marinalva Dantas, who coordinated a Mobile Inspection Team, are instructive..$^{23}$ Even though she recognizes that legally-recognized slavery was abolished in the nineteenth century, Dantas justifies the use of the term today. She argues that especially in the last few decades workers have been exploited in ways that are, owing to their inherent violence, commensurate with conditions imposed in the past on slave laborers. She recognizes that these maneuvers are not exactly a novelty in Brazil, but she insists that they have acquired specific and drastic characteristics. This is because of the "subtle" mechanisms of coercion employed, and the profile of the workers most affected: migrants, illiterates, undocumented immigrants, mentally and physically handicapped individuals, lepers, alcoholics, and the "non-existent" (i.e. people who have never been issued any official indentity document). All of these individuals already endure profound social exclusion.

Even though I have not identified which particular contemporary workers have been "enslaved," how they have been "enslaved," or the types of work they have been pressed into, ${ }^{24}$ it may be stated that the population of "present-day

23. Marinalva Dantas. Depoimento ao projeto História do Ministério do Trabalho e Emprego, CPDOC/FGV, 2006. I rely on this interview as well as on two unpublished articles Dantas has given me: "Escravos da fome: o perfil dos trabalhadores escravos no Brasil pós Lei Áurea" and "Peonês: vocabulário utilizado pelos escravos do Brasil contemporâneo."

24. See Gelba C. Cerqueira and others.eds., Trabalho escravo contemporâneo no Brasil: contribuições críticas para sua análise e denúncia (Rio: Ed. UFJR, 2008). 
slaves" bears little resemblance to the slave populations of the past, or to the slave-holding system in force back then. If I were to describe a current "slaveholding system," at its base it would be entirely different from that of the past. Nonetheless-and this is key-parties who invoke the resonance between now and the past are also quite aware of this discrepancy. While they acknowledge the differences, their objective is to identify an exploitative situation that is as degrading as slavery, given its historical context. Once more Ruth Vilela's testimony clarifies the matter:

[...] when you start comparing the two systems point by point, you can almost conclude that contemporary slavery in certain specific aspects is, without minimizing "classical" slavery, even worse than the latter. [. . .] Owing to a certain surfeit of laborers, today's slaves are expendable. They have no inherent economic value, they are not capital in the way that black slaves were. And as similar as the corporal punishments inflicted on both groups may be, slave-holders in the past had to make at least some effort to keep their slaves alive and healthy. That is not the case with contemporary slaves-they are entirely expendable. [...] On the other hand, "classical" slavery's shackles have been replaced by another type of shackle, which comes from the social isolation of the individuals and from their own sense of moral obligation [here Vilela alludes to workers' commitment to debts they feel they owe and need to pay.$^{25}$

With the acknowledgement of so many differences, then, on what juridical and political bases can we justify the use of the category? It appears that the matter of coercion and the deprivation of individuals' freedom, whether physical or moral, has been fundamental. This is a weighty argument for the reference to slavery. But the situation changed when the term was reinterpreted in the 2003 modification of Article 149 of the Penal Code. The arguments made for that modification are quite relevant: Brito Filho, an attorney with the State of Parás Public Ministry of Labor, expressed this very well. ${ }^{26}$ In his view, since legal slavery had been abolished by the Golden Law, legal debates on the matter of "labor analogous to slavery" needed to proceed in a different manner, and a different conceptualization of that phenomenon in contemporary society was needed. What seems to have happened, and what Brito Filho endorses, is a transformation of the bases on which it is legally acceptable to designate something as labor analogous to slavery. Brito Filho contends that up through the end of the twentieth century, the concept remained limited, resting on the

25. Ruth Vilela. Depoimento concedido ao projeto Historia do Ministério do Trabalho e Emprego. CPDOC/FGV, 2006, tape 2, 38.

26. I rely to a great extent on his interview and Brito Filho's article, "Trabalho com redução do homem à condição análoga a de escravo e dignidade da pessoa humana," http://www.pgt.mpt. gov.br (accessed in February 2007). 
principle of a direct denial of liberty. As discussions around the problems of labor became more prevalent, however, the idea expanded to include the broader field of human rights and the notion of "labor analogous to slavery."

In the contemporary context the law had to guarantee respect for "human dignity," defined as a group of rights that provide for the minimal existential conditions for human beings and their communities' self-determination. This relies on the understanding that, beyond liberty (i.e., the lack of physical and/ or symbolic constraints), it is also crucial to guarantee living and working conditions that distinguish human beings from other living creatures. Thus, added to the Penal Code was the concept of human dignity and human rights as an unalienable and non-negotiable dimension of social life. In the world of labor, this takes the form of "decent work," as stipulated both in our 1988 Constitution and in the Universal Declaration of Human Rights itself.

This is why the Penal Code not only now recognizes situations in which, in the "classical" sense, people are not free, but it also defines a "new" circumstance identified as a lack of respect for basic needs, entailing a specific form of exploitation of economic and sociocultural misery. In saying this Brito Filho creates some semantic slippage and expands what is understood to be slave-like labor, as such conditions were eventually characterized as a crime against workers' human rights rather than merely a crime against their rights as workers.

Within this line of thinking, there is no desire to make a direct juridical link to Brazil's slave-holding past-quite the contrary. This approach makes an effort to establish distance from that reality, to get beyond the basic legal notions of property and of usurping workers' freedom. Once participants in the labor market are legally free, a different set of bases define the notion of "labor analogous to slavery," that is, conditions of work constituting a crime against human rights. This category has acquired strength and meaning since the Second World War, and has become a key issue in international politics especially in light of the processes of globalization, which have only intensified since the 1980s. The revised Article 149 in the Penal Code asserts that in Brazil this lack of respect for human rights will not be granted impunity. It is unacceptable to subject human beings to humiliating working conditions that degrade their human dignity. Freedom is but one component of that dignity.

Considering that we are dealing with a modern social phenomenon to which equally modern juridical interpretive resources are being applied, why then has Brazil turned to a reference to its slave-owning past and not adopted the terminology of forced or compulsory labor? Why are so many social agents directly involved in the matter invested in this term even as they recognize they are not talking about the "slavery and slaves" of the nineteenth century?

If the term "labor analogous to slavery" has undergone a profound transformation and adjustment to conditions in the late twentieth and early twentyfirst centuries, it is equally obvious that this category retains immense symbolic value, insofar as it brings to mind the entire slave-holding past of Brazilian 
society. In that "past," which has been mobilized in the construction of our nation's memory, male and female workers were cruelly exploited as chattel slaves, in a specific mode that is not acceptable in today's world. Scholars and jurists alike have tried to set in motion not an identification with our slaveholding past in the sense of an "unacceptable return," but rather through a grasping of the term's explanatory and mobilizing potential, its capacity to aid in rapid comprehension of a new phenomenon that is widespread and complex and that must be situated in its own time.

For these reasons, and relying on an observation by Clifford Geertz in his classic essay in The Interpretation of Cultures, ${ }^{27}$ along with Neide Sterci's insightful interpretation of that piece, ${ }^{28}$ I propose here a different historical understanding of "labor analogous to slavery." This term is not a label, but rather a metaphor. It has been constructed through our discourse, and by those who have acted to combat these practices in today's world, especially in Brazil. Geertz maintains that metaphor is an operation that stratifies meaning. In a metaphor an incongruous meaning on one level produces an influx of meaning on another. ${ }^{29}$ In other words a metaphor imposes something on something else-something that the thing itself is not. Beyond this, the more inappropriate a particular metaphor may be, the more effective its explanatory power may be. Thus a metaphor's success or failure depends on its stylistic value and the related meanings it evokes in a given time and place. A good metaphor turns a "false affirmation" into a functioning analogy, i.e., into an effective and plausible interpretation of reality. In that way it becomes a symbol, an image capable of expressing a complex dimension of that reality to a broad and diverse public.

So by understanding "labor analogous to slavery" as a metaphor, we should also note that referring to workers as "slaves" indicates precisely that they are not slaves, and that it is intolerable to have slaves and slavery of any sort. What the political and legal discourse that is gaining currency in the popular media does through the use of the term is to communicate that there is real worker exploitation that must be extinguished. Within such media of communication one must use terms that have great communicative power, ones that in this case activate the nation's collective memory, a memory in which slavery as a system of labor relations has long been rejected. Consequently, to assert that this designation bears the "seal of anachronism" is, from a historical point of view, accurate. But precisely because of its anachronism, and because it triggers those national memories, its use has grown in broad and diverse sectors of Brazilian society, making it possible both to modify the criminal code accordingly, and to obtain the approval of the International Labor Organization for a terminological initiative that originated within Brazil itself.

27. Clifford Geertz, A interpretação de culturas (Rio: Zahar, 1978).

28. It is Sterci who points to this interpretive dimension.

29. Geertz, op. cit., 181-82. 